\title{
PENERAPAN WORK PREPARATION \\ DAN INTENSITAS PENDAMPINGAN PADA CAPAIAN PRESTASI \\ PRAKTIK PEMESINAN MAHASISWA JURUSAN MESIN \\ FAKULTAS TEKNIK UNIVERSITAS NEGERI YOGYAKARTA
}

\author{
Th. Sukardi \\ FT Universitas Negeri Yogyakarta (e-mail:thomkar234@yahoo.co.id; \\ HP 081328174979)
}

\begin{abstract}
Work Preparation and Coaching Intensity to Improve Mechanical Engineering Students' Academic Achievement in the Machinery Practicum in the Engineering Faculty of the Yogyakarta State University. This study aims to reveal the effects of the work preparation and coaching system for mechanical engineering students of the Engineering Faculty of the Yogyakarta State University on the $3^{\text {rd }}$ Machinery Practicum. This study was a classroom action research study. The population comprised all the students and the sample consisted of 19 3rd semester students. The data were collected through questionnaires, observations, and documents and analyzed by quantitative and qualitative descriptive techniques. The results are as follows. 1) The work preparation and coaching system ran well and was conducted in 10 weeks ( 2 cycles). The work preparation was made by the students before the class started. They consulted the lecturer 10 minutes before. The coaching was effective if it was carried out every 30 minutes since that class started. 2) The students passed this practicum if they obtained a score of 78.15 and successfully finished 5 of 7 jobs. 3) The process ran well and the students showed a good attitude towards work and worked seriously.
\end{abstract}

Keywords: work preparation, coaching intensity

\section{PENDAHULUAN}

Jurusan Mesin FT-UNY merupakan salah satu jurusan yang sudah bersertifikatISO sehingga semua prosedur yang ada dan dilaksanakan sudah berpedoman pada prosedur operasi standar yang ada. Pembelajaran praktik permesinan biasanya dilakukan dengan peralatan yang ada di bengkel pemesinan dengan segala fasilitas dan perlengkapannya,yang secara kurikuler sudah terstruktur dan terencana dengan baik. Seperangkat kompetensi yang akan dica- pai oleh mahasiswa dioperasionalkan dalam bentuk Job sheet, dan dalam pelaksanaannyamahasiswadiwajibkan menyelesaikan kompetensi tersebutdengan berpedoman pada job sheet yang sudah dibakukan oleh jurusan. Job sheet yang adadiJurusan Mesin FT-UNY dibuat dengan baik melalui proses verifikasi yang panjang dan terstandar, dengan harapan job sheet tersebut dapat dipakai sebagai pedoman pada PBM praktik di bengkel pemesinan. Kondisi yang nampak di lapangan sangat berbeda, hal 
tersebut disebabkan karena kurangnya kontrol dan pengawasan dari pihak pengelola, dosen/instruktur yang bertanggung jawab, maka pelaksanaan proses belajar mengajar (PBM) praktik Jurusan Mesin FT-UNY tidak dapat berjalan lancar, hal tersebut ditandai dengan tidak selesainyaseperangkat kompetensi yang harus dikuasai oleh mahasiswa dalam waktu satu semester.

Hasil observasi dan pengalaman di lapangan menunjukkan bahwa mahasiswa masih banyak yang kurang memahami tentang proses kerja praktik permesinan, hal tersebut terjadi karena banyak mahasiswa yang kurang memahami dan tidak memanfaatkan job sheet yang telah disediakan oleh dosen/instruktur. Bukti faktual tersebut terjadi karena mereka tidak paham tentang manfaat job sheet, sehingga dalam mengerjakan job kompetensi dilakukan secara asal-asalan, akibatnya benda kerja rusak atau ukurannya di luar standar yang telah ditetapkan. Kondisi tersebut juga diperparah oleh cara pendampingan yang ditempuh oleh dosen/instructor yang bertanggung jawab mengampu PBM praktik, yang terlihat selama ini dosen kurang intensif dalam melakukan pendampingan kepada para mahasiswa. Dosen tidak melakukan kontrol, tidakmelakukan pengawasan, tidak memantaudantidak aktif membimbing mahasiswa selama PBM praktik berjalan, dengan demikian mahasiswa berjalan semaunya sendiri. Sementara itu, kondisi dan jumlah mesin/alat yang terbatas, usia mesin/peralatan yang sudah tua, dan banyak yang mengalami kerusakan, maka kondisi tersebut juga berakibat pada ketidak sesuaian langkah kerja yang ada pada job sheet yang harus dikerjakan oleh mahasiswa. Selain itu, rasio mesin dan mahasiswa menjadi terlalu tinggi, sehingga satu mesin dipakai praktik oleh dua atau tiga orang mahasiswa, dengan kata lain mesin/alat yang ada tidak mampu melayani proses belajar mengajar secara optimal.

Untuk meningkatkan pemahaman mahasiswa tentang fungsi job sheet, maka dipandang perlu untuk memberikan pelatihan kepada para mahasiswa yang akan malaksanakan praktik permesinan agar mahasiswa memperoleh pemahaman yang lebih baik dan akan melaksanakan praktik dengan optimal. Untuk itu dalam penelitian ini akan diterapkan pola pembuatan persiapan kerja (work preparation atau WP) kepada para mahasiswa Jurusan Mesin FT UNY yang melaksanakan pembelajaran praktik pemesinan di bengkel mesin. WP dalam pelaksanaannya dibuat oleh mahasiswa menurut persepsi masing-masing yang kemudian dikonsultasikan kepada dosen/instruktor yang bertanggung jawab untuk mendapatkan rekomendasi apakah dapat digunakan atau tidak, atau perlu diperbaiki agar dapat dipakai sebagai pedoman dalam mengerjakan job kompetensi.Dalamimplementasinya dosen dituntut aktif dalammelakukan pendampingan, harus memantau, mengawasi dan membimbing jika mahasiswa mengalami kesulitan dalam mengerjakan job kompetensi dan WP yang telah dibuatnya.

Praktik permesinan adalah bentuk proses pembelajaran produktif yang mengajarkan materi kompetensi permesinan kepada para mahasiswa yang ingin menguasai kompetensi tersebut 
dengan cara atau metode yang baku dan benar. Kompetensi permesinan tersebut meliputi kompetensi membubut, mengefrais,mengebor,menggerinda rata dan silinder, menyekrap menggergaji, memarut dan lain sebagainya. Kegiatan ini dapat berlangsung jika didukung oleh beberapa aspek pokok yaitu: aspek fasilitas praktik, bahan praktik, uruturutan kegiatan pembelajaran atau Rencana Pelaksanaan Pembelajaran (RPP), job sheets/operation sheets/instruction sheets, dosen, teknisi, mahasiswa, dan aspek-aspek pendukung lainnya. Salah satu aspek yang paling dominan dalam proses pembelajaran praktik permesinan adalah keberadaan job sheet, karena job sheet dipakai untuk pemandu atau pegangan mahasiswa dalam mempelajari dan menguasai salah satu kompetensi yang diajarkan oleh pendidik.

Menurut Leighbody (1968:67-68), ada dua jenis job sheet yang digunakan dalam pebelajaran praktik yaitu: job produksi (productions job) dan job kombinasi (combining exercises and production jobs). Jika akan menggunakan job produksi, maka isi dan jenis job yang akan digunakan harus dianalisis secara detail, dipilih dan disesuaikan dengan tujuan. Jumlah job harus dipertimbangkan secara detail berapa yang harus dikuasai oleh mahasiswa, seberapa jauh kemampuan mahasiswa untuk menyelesaikan job tersebut. Jika akan memakai job kombinasi maka harus ditentukan juga isi job, jenis dan jumlah job (dalam hal ini job kompetensi dan job produksi).

Bentuk penulisan dan penggunaan job yang sering digunakan dalam pembelajaran praktik yaitu: job sheet dan ope- ration sheet. Job sheet berisi tentang langkah-langkah pengerjaan yang harus diikuti oleh mahasiswa dalam mengerjakan suatu jenis pekerjan, dan biasanya dalam job sheet disertakan pula gambar kerja beda yang akan dibuat mahasiswa. Operation sheet berisi tentang langkah-langkah mengoperasikan peralatan praktik dalam rangka untuk mengerja kan benda kerja, dengan harapan benda kerja jadi namun penggunaan mesin juga sesuai prosedur kerja misalnya, pada praktik permesinan numerically control atau permesinan NC (DeGarmo, 2003: 1042-1043). Kedua jenis lembar kerja tersebut dalam pelaksanaannya ada yang betuknya lengkap (langkah kerja dan gambar ada), dan ada yang tidak lengkap yaitu biasanya hanya gambar kerja yang ada sedangkan langkah kerjanya tidak ada, ini biasanya diterapkan untuk pendekatan strategi pembelajaran problem solving pada mahasiswa.

PBM praktik di Jurusan Mesin FT UNY menuntut banyak fasilitas dan prosedur yang cukup, terencana dan terstruktur. Dalam pelaksanaannya memerlukan kesungguhan dan komitmen yang benar-benar kompak baik di jajaran manajerial ataupun di tingkat operasional. Kenyataan di lapangan banyak kendala yang dihadapai untuk pelaksanannya, antara lain: Kurangnya bahan dan fasilitas untuk pelaksanaan proses pembelajaran praktik; fasilitas praktik banyak yang rusak karena tidak ada maintenance; dana untuk pelaksanaan pembelajaran praktik masih sangat kurang; kompetensi dosen/instruktur masih kurang menguasai pada bidangnya; komitmen sumber daya manusia yang ada (dosen, instruktor, teknisi, pe- 
ngelola) masih kurang; proses pembelajaran praktik di bengkel mesin dan pengelolaannya masih belum baik penanganannya; struktur dan perangkat bantu kompetensi (seperti job sheet, silabus, dlsb) belum lengkap.

Berdasarkan kondisi dan kendalakendala tersebut, maka permasalahan yang akan dipecahkan dalam penelitian ini dibatasi pada aspek PBM praktik yang menyangkut masalah intensitas pendampingan (komitmen dan kompetensi dosen dalam mengajar) dan masalah perangkat bantu kompetensi (job sheet, dalam hal ini penerapan WP).

- Bagaimana capaian prestasi praktik mahasiswa dengan menggunakan WP?

- Bagaimana capaian prestasi praktik mahasiswa dengan adanya intensitas dosen melakukan pendampingan?

- Bagaimana perilaku kerja mahasiswa dengan adanya WP dan intensitas pendampingan dosen?

\section{METODE}

Penelitian ini akan meneliti tentang penerapan WP dan intensitas pendampingan yang dilakukan oleh dosen pada kelas praktikum di bengkel pemesinan. Jenis penelitian yang dipakai adalah penelitian tindakan kelas (classroom action research) jenis partisipan langsung (participatory action research)dengan alasan penelitian dilakukan dengan keterlibatan langsung peneliti dari awal sampai akhir proses sebagai bentuk tindakan pemecahan masalah kelas. Konsep pokok penelitian tindakan kelas (action research) menurut Kurt Lewin terdiri dari empat komponen, yaitu: (1) perencanaan (planning); (2) tindakan (acting),
(3) pengamatan (observing); dan (4) refleksi (reflecting), dan hubungan keempat komponen itu di sebagai satu siklus. Lokasi penelitian dilaksanakan di bengkel kerja praktik Jurusan Mesin FTUNY selama 4 bulan mulai Juli sampai dengan Oktober 2009. Populasi dalam penelitian ini adalah mahasiswa Program Studi Teknik Mesin FT-UNY dengan sampel 19 mahasiswa semester 3 kelas A. Data informasi tentang WP diambil dengan menggunakan metode angket, data intensitas pendampingan diambil dengan observasi dan data prestasi kerja praktik diambil dari dokumentasi dosen/instructor praktik. Data hasil isian angket dan data prestasi hasil kerja praktik mahasiswa dianalisis dengan teknik deskriptif dan korelasional, sedangkan data hasil dari wawancara dan observasi di lapangan dianalisis dengan teknik deskriptif kualitatif, artinya menjelaskan secara rinci segala fenomena yang didapat dari lapangan. Rencana tindakan yang akan dilaksanakan pada penelitian ini mengacu pada model tindakan yang dikembangkan oleh Kurt Lewin (lihat Gambar 1). 


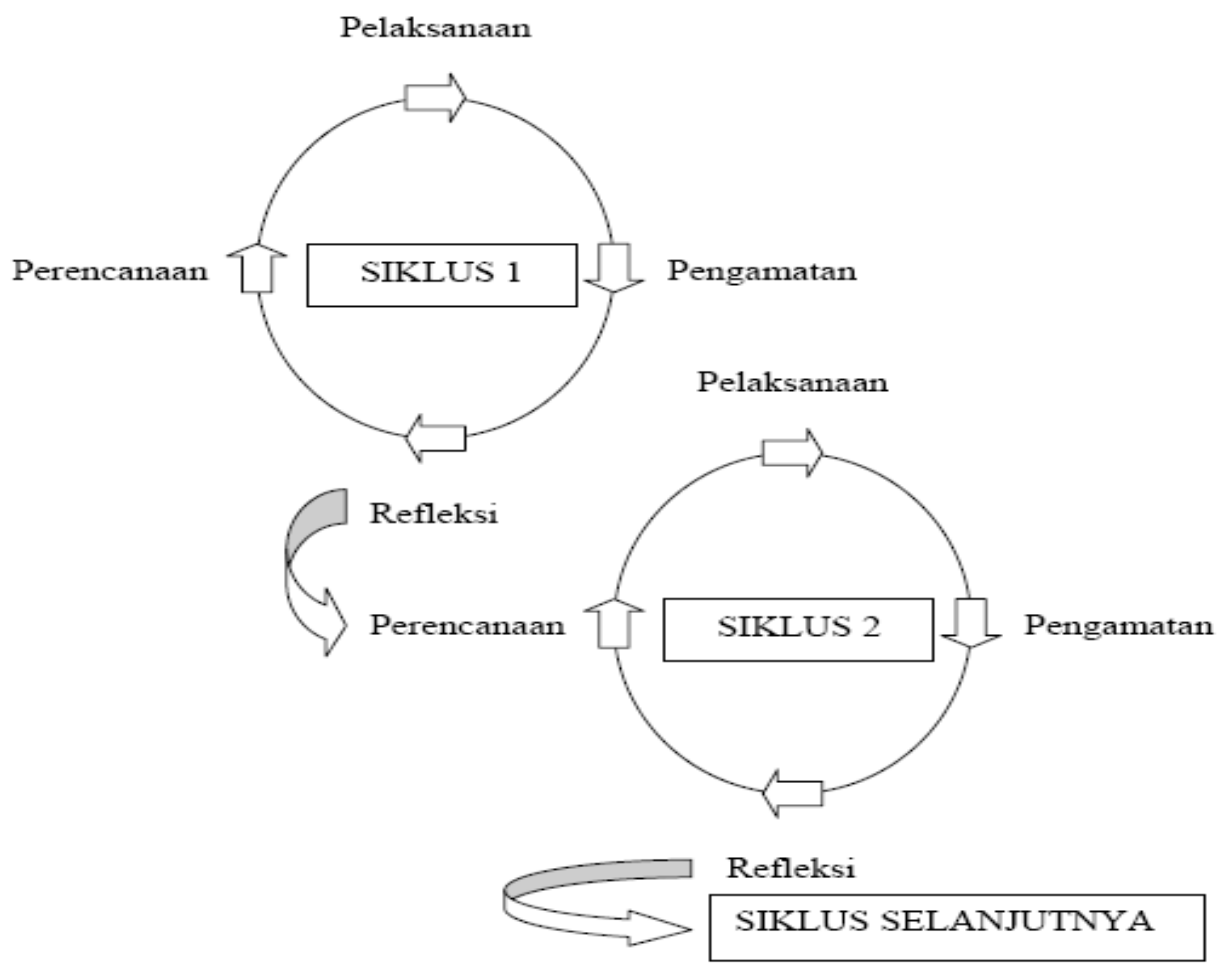

Gambar 1. Siklus Tindakan Proses Penelitian menurut Kurt Lewin

\section{HASIL PENELITIAN}

Hasil penelitian yang dimaksud adalah hasil dari pelaksanaan tindakan yang diberikan kepada kelas A (19 mahasiswa) dan dua kelas pembanding (kelas B dan C) lainnya. Fokus amatan pada pelaksanaan proses penggunaan lembar kerja atau WP dan pendampingan, yang hasilnya dipaparkan tiap tahapan pada siklus tindakan sebagai berikut ini.

\section{SIKLUS I}

\section{Perencanaan pada siklus I}

Pada tahapan perencanaan ini yang dilakukan oleh peneliti sebagai berikut.

Pertama, melakukan kajian dan mengidentifikasi materi lembar kerja (job sheet), pada tahapan ini ditawarkan kepada mahasiswa berbagai bentuk lembar kerja yang biasa dipakai di industri pemesinan dan lembaga pendidikan teknologi dan kejuruan rumpun teknologi industri. Kedua, membentuk kelompok diskusi untuk membahas materi lembar kerja yang ditawarkan untuk dipilih. Penawaran pemilihan lembar kerja dilakukan dengan cara diskusi kelompok (dalam hal ini ada 4 kelompok) kemudian ditentukan mana yang dipilih untuk digunakan dalam proses pembelajaran Praktik Pemesinan 3. Ketiga, diskusi didampingi, diawasi dan diarahkan agar mahasiswa dapat menentukan bentuk lembar kerja yang akan digunakan berdasarkan pertim- 
bangan nalar masing-masing. Keempat, pendampingan direncanakan setiap 50 menit sekali secara rutin. Kelima, bentuk lembar kerja yang ditawarkan terse- but diistilahkan sebagai berikut yaitu, operation sheet, rencana proses, persiapan kerja, routing sheet, dan bentuk gambar kerja.

Table 1. Bentuk Persiapan Kerja (Work Preparation)

\begin{tabular}{|c|c|c|c|c|c|c|c|c|c|c|}
\hline \multirow{2}{*}{ No } & \multirow{2}{*}{$\begin{array}{l}\text { Jenis } \\
\text { kerja }\end{array}$} & \multirow{2}{*}{$\begin{array}{l}\text { bMesin/alat } \\
\text { digunakan }\end{array}$} & \multirow{2}{*}{$\begin{array}{l}\text { ygAlat } \\
\text { potong }\end{array}$} & \multicolumn{4}{|c|}{ Parameter pemotongan } & \multirow{2}{*}{$\begin{array}{l}\text { Estimates } \\
\text { waktu }\end{array}$} & \multirow{2}{*}{$\begin{array}{l}\text { Langkah } \\
\text { kerja }\end{array}$} & \multirow{2}{*}{$\begin{array}{l}\text { Kes. } \\
\text { kerja }\end{array}$} \\
\hline & & & & cS & feed & $\mathrm{n}$ & h & & & \\
\hline$\overline{1}$ & $\begin{array}{l}\text { Membubut } \\
\text { facing } \\
\text { gambar }\end{array}$ & $\begin{array}{l}\text { Mesin bubut } \\
\text { Chuck } 3\end{array}$ & $\begin{array}{l}\text { Pahat } \\
\text { facing }\end{array}$ & 45 & 0.02 & 550 & 0,2 & 10 menit & $\begin{array}{l}\text { 1.cekam } \\
\text { 2.facing } \\
\text { 3.dst }\end{array}$ & $\begin{array}{l}\text { Pakai } \\
\text { coolant }\end{array}$ \\
\hline
\end{tabular}

Hasil tahap perencanaan ini ditandai dengan dipilihnya lembar kerja yang telah direncanakan sebelumnya. Dari kelima bentuk tersebut setelah melalui diskusi yang panjang akhirnya disetujui oleh semua mahasiswa yang bentuk persiapan kerja (tabel 1), tentu saja dengan berbagai pertimbangan, yaitu di antaranya bentuk ini mudah dipahami pemakaiannya, kemudahan untuk difahami, parameter pemesinan komplit, dan ada gambar skemanya, serta mudah pembuatannya.

\section{Pelaksanaan}

Pada tahapan ini melakukan uji coba penerapan WP kepada mahasiswa, dengan prosedur 1) pembuatan WP dilakukan pada 30 menit sebelum pembelajaran praktik dimulai; 2) pada waktu pembuatan WP, dosen mengawasi dan mendampingi mahasiswa yang berfungsi sebagai nara sumber; 3) mahasiswa menulis dan melakukan konsultasi mengenahi WP yang telah dibuatnya untuk mendapatkan rekomendasi oleh dosen bahwa WP yang dibuat laik untuk digunakan; 4) penggunaan WP sebagai pedoman mahasiswa dalam melaksanakan praktik Pemesinan 3; 5) selama menggunakan WP dosen melakukan pengawasan dan pendampingan setiap 50 menit secara rutin.

\section{Pengamatan/Observasi}

Melakukan observasi intensitas pendampingan yang dilakukan oleh dosen dalam rangka menerapkan WP yang telah dibuat oleh mahasiswa. Hasil yang dapat dijelaskan pada tahapan ini adalah: 1) pendampingan dilaksanakan setiap 50 menit sejak dari praktikum dimulai; 2) selama pendampingan dan pengawasan dilakukan terlihat bahwa sikap kerja mahasiswa sudah ada niat menunjukkan sikap kerja yang aman dan tertib; 3) mahasiswa belum semuanya selalu berpedoman pada WP yang telah dibuatnya, masih lupa atau kurang terbiasa; 4) mahasiswa bekerja serius untuk menyelesaikan job yang dikerjakannya; 5) waktu praktik efektif relatif berkurang karena terpotong pembuatan WP 30 menit, dan persiapan awal serta akhir. 
Tabel 2. Dampak Tindakan Siklus 1

\begin{tabular}{|c|c|c|}
\hline No & Tindakan & Dampak \\
\hline 1 & $\begin{array}{l}\text { Pemberian dan pemilihan } \\
\text { model WP oleh dosen. }\end{array}$ & $\begin{array}{l}\text { a. Mahasiswa mengalami kebingungan dengan } \\
\text { model WP yang ditawarkan dosen. } \\
\text { b. Mahasiswa dapat menentukan pilihannya ten- } \\
\text { tang model WP yang akan digunakan. }\end{array}$ \\
\hline 2 & $\begin{array}{l}\text { Mahasiswa melakukan pem- } \\
\text { buatan WP dengan format } \\
\text { yang telah dipilihnya. }\end{array}$ & $\begin{array}{l}\text { a. Mahasiswakesulitan menentukanparameter pe- } \\
\text { mesinan, sumber acuan terbatas. } \\
\text { b. Mahasiswa menjadi aktif diskusi antar maha- } \\
\text { siswa dan melakukan konsultasi pada dosen. } \\
\text { c. Waktu praktik agak tersita untuk pembuatan } \\
\text { WP. }\end{array}$ \\
\hline 3 & $\begin{array}{l}\text { Pemakaian WP untuk pedo- } \\
\text { man praktik dengan dipan- } \\
\text { tau dosen. }\end{array}$ & $\begin{array}{l}\text { a. Mahasiswa belum terbiasa memakai WP seba- } \\
\text { gai pedoman kerja, masih banyak bertanya pa- } \\
\text { da teman kerjanya, belum mandiri. } \\
\text { b. Cara kerja mahasiswa ada sedikit kemajuan } \\
\text { menjadi aktif. }\end{array}$ \\
\hline
\end{tabular}

\section{Analisis dan Refleksi}

Hasil analisis dan refleksi yang didapat dalam pelaksanaan penggunaan WP dan intensitas pendampingan dosen dalam praktik Pemesinan 3 secara garis besar dijelaskan sebagai berikut. Pertama, kecepatan mahasiswa dalam mengerjakan $j o b$ ada kemajuan yang positip, karena sistim bekerjanya sudah agak cermat serta teliti tidak sembarangan. Kedua, mahasiswa masih ada yang nampak belum terbiasa menggunakan WP sebagai pedoman kerja. Ketiga, efek pendampingan dosen setiap 50 menit ternyata belum dapat mempengaruhi sistim kerja mahasiswa secara sempurna. Keempat, roses kerja sudah menunjukkan ada indikasi berjalan aman dan terkendali, baik untuk mesin, benda kerja maupun operatornya, namun hal tersebut belum sepenuhnya memenuhi harapan yang diinginkan. Kelima, pembuatan WP ternyata lebih baik jika dilakukan sebelum melakukan kegiatan praktik pada hari pelaksanaan- nya (dikerjakan di luar jadwal praktik). Keenam,ari pelaksanaan dapat diamati bahwa proses pendampingan dan pengawasan pelaksanaan praktik akan lebih mengena jika dosen sering melakukan shock theraphy, yaitu melakukan penjajagan secara tiba-tiba pada salah satu mahasiswa yang kurang komit pada kerjanya. Ternyata kegiatan ini dapat mengurangi kegagalan kerja, kecelakaan kerja, serta ketidakdisiplinan mahasiswa.

\section{SIKLUS II}

Hasil analisis dan refleksi menunjukkan bahwa pada siklus I masih terdapat beberapa kekurangan yang belum memenuhi kelancaran pelaksanaan WP dan pendampingan. Untuk itu pada siklus II akan diadakan perbaikan-perbaikan agar didapatkan hasil seperti yang diharapkan. 


\section{Perencanaan pada siklus II}

Pada aspek perencanaan ini, hal yang pokok perlu direncanakan kembali sebagai berikut.

- Pembuatan WP dibuat sebelum praktik dimulai, tepatnya job minggu depan diberikan pada akhir pembelajaran praktik saat itu, yang kemudian pembuatan WP dapat dikerjakan di rumah atau di bengkel sebelum waktu pembelajaran dimulai bersamasama dengan kelompok kerjanya.

- Konsultasi WP dilakukan dibengkel padawaktuakan praktik dengan waktu yang relatip singkat \pm 10 menit.

- Pendampingan dilakukan dalam selang waktu yang relatife pendek yaitu setiap 30 menit secara rutin.

- Mengintensifkan pendampingan dengan konsentrasi penuh pada penggunaan WP, berusaha membiasakan penggunaan WP kepada mahasiswa agar dipakai sebagai pedoman kerja.

- Melakukan shock theraphy kepada mahasiswa, yaitu dengan melakukan penjajagan secara tiba-tiba pada salah satu mahasiswa yang kurang komit pada kerjanya.

\section{Pelaksanaan}

- Pembuatan WP dilakukan di luar jam pembelajaran praktik, sehingga waktu praktik tidak tersita terlalu banyak.

- Konsultasi WP dapat diperpendek waktunya, dilakukan sesuai waktu yang direncanakan \pm 10 menit.

- Waktu pendampingan diperpendek menjadi tiap 30 menit dan dilakukan secara rutin.

- Dosen melakukan shock theraphy untuk melakukan penjajagan kemam- puan kerja mahasiswa selama praktik.

- Menerapkanregulasiketatkepada mahasiswa agar memakai WP sebagai pedoman kerja praktik.

\section{Observasi}

Dari hasil observasi pelaksanaan penerapan WP dan intensitas pendampingan dosen terlihat bahwa secara garis besar dapat dikatakan sesuai dengan yang diharapkan.

- Dengan dibuatnya WP di luar jam pelaksaan pembelajaran praktik, ternyata hasilnya lebih sempurna, format rapi, isinya komplit dan tidak mengurangi jam pembelajaran praktik.

- Denganwaktu konsultasi WP \pm 10 menit ternyata tidak mengurangi waktu pelaksanaan pembelajaran praktik.

- Pendampingan yang dilaksanakan tiap 30 menit secara rutin berjalan baik dan dirasakan sangat efektif untuk pengawasan kepada mahasiswa.

- Shock theraphy yang dilakukan dosen memacu kesiapan dan perhatian siswa dalam melaksanakan pembelajaran praktik. Mereka selalu siap dan bersikap kerja yang baik.

- Dengan regulasi yang ketat dan ada hukuman akademis bagi yang tidak menggunakan WP sebgai pedoman, maka mahasiswa menjadi patuh untuk menggunakan WP sebagai pedoman kerja mereka.

- Dengan penggunaan WP dan intensitas pendampingan yang rutin, sikap kerja mahasiswa cenderung menjadi sikap yang aman, baik untuk mesin maupun benda kerja serta lingkungannya. 
Table 3. Dampak Tindakan Siklus II

\begin{tabular}{|c|c|c|}
\hline No & Tindakan & Dampak \\
\hline 1 & $\begin{array}{l}\text { a. Pembuatan WP dilakukan diluar } \\
\text { jam pembelajaran praktik. } \\
\text { b. Job minggu depan diberikan pa- } \\
\text { da akhir pembelajaran praktik. }\end{array}$ & $\begin{array}{l}\text { WP dikerjakan diluar jam pembelajaran } \\
\text { praktik, ternyata didapatkan hasil yang lebih } \\
\text { sempurna, format rapi, isinya komplit dan } \\
\text { tidak mengurangi jam pembelajaran praktik. }\end{array}$ \\
\hline 2 & $\begin{array}{l}\text { Mengintensifkan pendampingan se- } \\
\text { tiap } 30 \text { menit. }\end{array}$ & $\begin{array}{l}\text { a. Mahasiswa menjadi tekun dan serius da- } \\
\text { lam bekerja. } \\
\text { b. Jika terjadi kesulitan dan kesalahan pro- } \\
\text { sedur kerja cepat teratasi. }\end{array}$ \\
\hline 3 & $\begin{array}{l}\text { Pembiasaan penggunaan WP seba- } \\
\text { gai pedoman kerja praktik. }\end{array}$ & $\begin{array}{l}\text { a. Hasil kerja praktik menunjukkan prestasi } \\
\text { yang memuaskan, nilai rata-rata yang di- } \\
\text { dapat adalah } 78,15 \text {. } \\
\text { b. Prosentase kumulatif pengumpulan job } \\
\text { tinggi }\end{array}$ \\
\hline 4 & $\begin{array}{l}\text { Melakukan shock theraphy kepada } \\
\text { mahasiswa, sebagai cek kesiapan } \\
\text { kerja. }\end{array}$ & $\begin{array}{l}\text { a. Mahasiswa menjadi komit akan tugasnya } \\
\text { dalam melakukan kerja praktik. } \\
\text { b. Dapat mengurangi terjadinya kegagalan } \\
\text { kerja, kesalahan kerja, kecelakaan kerja, } \\
\text { serta ketidakdisiplinan kerja mahasiswa. }\end{array}$ \\
\hline
\end{tabular}

\section{Analisis dan Refleksi}

Dari hasil observasi siklus II mengindikasikan bahwa pada siklus ini penerapan WP dan intensitas pendampingan sudah berjalan sesuai yang diharapkan. Hal tersebut terlihat beberapa bukti hasil refleksi berikut.

- Dengan mengambil pengalaman di lapangan ada hal-hal yang perlu dievaluasi dan direvisi pelaksanaannya yaitu, pembuatan WP ternyata lebih baik jika dilakukan sebelum melakukan kegiatan praktik pada hari pelaksanaannya (dikerjakan di luar jadwal praktik). Ternyata hal ini hasilnya sangat efektif kecepatan siswa atau jumlah job yang dikerjakannya akan lebih banyak, karena tidak menyita jam pembelajaran praktik.

- Dari pelaksanaan dapat diamati bahwa proses pendampingan dan pengawasan pelaksanaan praktik akan le- bih mengena jika dosen sering melakukan shock theraphy, yaitu melakukan penjajagan secara tiba-tiba pada salah satu mahasiswa yang kurang komit pada kerjanya. Ternyata kegiatan ini dapat mengurangi kegagalan kerja, kecelakaan kerja, serta ketidakdisiplinan mahasiswa.

- Dalam pelaksanaan WP dan pelaksanaan pendampingan kepada mahasiswa yang sedang melakukan praktik, ternyata memerlukan komitmen yang sangat tinggi. Dosen harus sadar akan tugas dan tanggung jawabnya, artinya harus selalu mengontrol dan menasehati serta memberikan contoh kerja yang benar dan baik kepada mahasiswa.

- Hasil kerja praktik menunjukkan prestasi yang memuaskan, hal ini dapat dilihat dari prosentase kumulatif pengumpulan job untuk masing-ma- 
sing kelas seperti berikut ini: Kelas A (kelas tindakan, dengan jumlah mahasiswa 19 orang) pada minggu ke 10 sudah mengumpulkan/selesai mengerjakan 5 job atau 71,4\% dari 7 job yang harus dikerjakan, capaian nilai rata-rata yang didapat adalah 78,15. Sebagai gambaran untuk kelas yang lain Kelas B (16 orang) pada minggu ke 10 baru mengumpulkan 4 job atau $57,14 \%$, dan Kelas C (17 orang) baru selesai mengerjakan 3 job atau 42,8\% dari 7 job yang harus dikerjakan.

\section{PEMBAHASAN}

Hasil penelitian menunjukkan bahwa capaian prestasi kelas yang diberi perlakuan penerapan WP dan pendampingan yang intensif lebih tinggi ratarata nilai yang dapat dicapai, yang secara rinci capaian tersebut adalah: Kelas A (kelas tindakan, dengan jumlah mahasiswa 19 orang) pada minggu ke 10 sudah mengumpulkan/selesai mengerjakan 5 job atau 71,4\% dari 7 job yang harus dikerjakan, capaian nilai rata-rata yang didapat adalah 78,15. Sebagai gambaran untuk kelas yang lain Kelas B (16 orang) pada minggu ke 10 baru mengumpulkan 4 job atau 57,14\%, dan Kelas C (17 orang) baru selesai mengerjakan 3 job atau $42,8 \%$ dari 7 job yang harus dikerjakan.

Gambaran hasil tersebut menunjukkan bahwa dalam suatu pembelajaran terutama praktik, jika diberi perlakuan yang terprogram dan dilaksanakan dengan sepenuh hati serta penuh tanggung jawab maka akan memberikan hasil capaian yang positip. Pembelajaran praktik pada dasarnya memerlukan keterampilan yang prima, keterampilan tersebut dapat dikuasai jika dilakukan dengan bimbingan yang benar dan intensif oleh dosen yang mengampu. Mahasiswa dilatih untuk memecahkan problematika kerja pemesinan, dengan WP ternyata membuat mahasiswa aktif menyelesaikan problematikanya, mereka dituntut mengetahui dan belajar teoriteori yang diperlukan dalam praktik pemesinan, seperti penguasaan alat potong, memahami parameter-parameter pemotongan, seting benda kerja yang benar dan aman, langkah kerja yang aman dan benar, serta problematika yang lainnya. Mahasiswa dituntut belajar mengungkap kembali teori yang telah dipelajarinya untuk diaplikasikan dalam lembaran kerja bentuk WP yang akan digunakan menjadi pedoman mereka dalam kerja praktik. Dengan WP maka akan melatih dan membuat mahasiswa menjadi cerdas serta terampil dalam menyelesaikan problematika dalam pembelajaran praktik

Penggunaan WP oleh dosen dalam pembelajaran praktik bengkel sebenarnya merupakan strategi dosen untuk membangkitkan aktivitas maupun kreatifitas mahasiswa dalam mengerjakan job yang harus diselesaikan. Tujuannya agar mahasiswa dapat menyelesaikan seluruh job yang harus ditempuh dengan hasil kerja/produk yang berkualitas baik dan dalam waktu yang relative cepat. Strategi penggunaan WP ini sejalan dengan pendapatnya Heywood (2005:225) yaitu, bahwa dalam pembelajaran praktik di laboratorium tidak ada metode kerja yang sifatnya tunggal untuk mengerjakan semua job, praktikan (mahasiswa) dilatih untuk menentukan langkah kerja dan strategi kerja 
yang harus dilakukan. Dan satu hal yang potensial disepakati dalam pembelajaran bengkel kerja adalah, bahwa jenis belajar dan performa yang dicapai peserta didik (mahasiswa) itu merupakan kompilasi dari keterampilan psikomotor peserta didik seperti, prosedur kerja, prosedur keselamatan kerja, keterampilan berfikir/kreatifitas, sikap serta keterampilan sosial (Saran, 1982:101). Dengan demikian penggunaan WP merupakan hal yang utama dan wajib untuk dilaksanakan demi kelancaran pembelajaran praktik dan kualitas produk kerja mahasiswa, yang akhirnya dapat meningkatkan prestasi mahasiswa.

Pendampingan dosen selama mengampu pembelajaran praktik mahasiswa sangatlah menentukan sekali terhadap penguasaan kompetensi mahasiswa. Peran dosen sangat dominan dalam kegiatan ini, karena misi pembelajaran praktik ini mendidik mahasiswa terampil pada bidangnya serta cerdas dalam menyelesaikan problema produksi pemesinan. Untuk itu pendampingan sangat diperlukan, dalam hal ini dosen dituntut untuk peka terhadap kondisi mahasiswa, wajib memberi arahan jika mahasiswa salah dalam menjalankan praktik, wajib memberi contoh jika mahasiswa mengalami kesulitan menggunakan mesin, wajib memberikan metode-metode kerja yang benar, cara-cara menggunakan mesin atau peralatan yang asing bagi mahasiswa.

Banyak keterampilan nonteknis dosen yang harus ditempuh untuk suksesnya kerja praktik, tujuannya agar mahasiswa lancar dalam mengerjakan job yang harus diselesaikan. Pendamping- an adalah salah satu bentuk keterampilan yang harus dikuasai oleh dosen dalam pembelajaran praktik, banyak cara yang bisa dilakukan oleh dosen untuk melakukan pendampingan yang semuanya tertuju pada kesuksesan mahasiswa dalam melakukan praktik. Prinsip pendampingan ini senada dengan pendapatnya Wankat dan Oreovicz (1993: 184), yaitu dalam pembelajaran praktik mahasiswa belajar dengan mengerjakan job, hal tersebut akan efektif belajarnya jika dibimbing dan diawasi proses belajar praktiknya. Dibimbing dan diawasi dalam hal ini sama artinya dengan melakukan pendampingan karena dalam pendampingan selain melakukan pembimbingan juga melakukan pengawasan secara langsung..

Pendampingan akan berjalan lancar jika diikuti oleh adanya komitmen dosen sebagai pengampu pembelajaran praktik. Dalam hal ini dosen harus komitmen akan tugasnya, tanggung jawabnya, serta perannya sebagai orang yang diteladani oleh mahasiswanya. Artinya, dosen memang dituntut untuk aktif selama pembelajaran, melakukan pendampingan secara rutin tiap 30 menit, dengan selalu ingat dan merasa bahwa "dosen banyak duduk merasa malu dengan mahasiswa yang bekerja" demikian pula tanamkan semboyan pada mahasiswa bahwa "mahasiswa juga harus merasa malu jika hanya diam tidak bekerja".

\section{KESIMPULAN}

Dari hasil penelitian tentang "Penerapan WP dan intensitas pendampingan pada caapaian prestasi praktik pemesinan mahasiswa program studi tek- 
nik mesin FT-UNY" dapat disimpulkan sebagai berikut.

Pelaksanaan WP dan intensitas pendampingan dosen berjalan baik sesuai dengan yang diharapkan, waktu pelaksanaan memerlukan \pm 10 minggu ( atau 2 kali siklus tindakan). WP dibuat dan dipersiapkan oleh mahasiswa di luar waktu pembelajaran praktik, dan konsultasi WP dilakukan sebelum praktik dengan lama waktu \pm 10 menit. Pendampingan yang dilakukan dosen akan efektif jika dilaksanakan setiap 30 menit secara rutin sejak dari praktikum dimulai.

Capaian prestasi mahasiswa di kelas A (kelas yang diberi tindakan) relatip baik hal tersebut ditandai dengan capaian rata-rata nilai praktik sebesar 78,15 . Serta diikuti kecepatan mengerjakan, dalam hal ini mahasiswa dapat mengumpulkan 5 job atau $71,4 \%$ dari 7 job yang harus dikerjakan.

Proses kerja berjalan aman dan terkendali, baik untuk mesin, benda kerja maupun operatornya. Selama pendampingan dan pengawasan dilakukan terlihat bahwa sikap kerja mahasiswa menunjukkan sikap kerja yang aman dan tertib, mahasiswa selalu berpedoman pada WP yang telah dibuatnya, mahasiswa bekerja serius untuk menyelesaikan job yang dikerjakannya.

\section{SARAN}

Pembuatan WP lebih baik jika dilakukan sebelum melakukan kegiatan praktik pada hari pelaksanaannya (dikerjakan di luar jadwal praktik), karena tidak menyita jam pembelajaran praktik.
Proses pendampingan dan pengawasan pelaksanaan praktik akan lebih mengena jika dosen sering melakukan shock theraphy, yaitu melakukan penjajagan secara tiba-tiba pada salah satu mahasiswa yang kurang komit pada kerjanya.

Penggunaan WP dan pelaksanaan pendampingan kepada mahasiswa yang sedang melakukan praktik, memerlukan komitmen dosen yang sangat tinggi. Dosen harus sadar akan tugas dan tanggung jawabnya, artinya harus selalu mengontrol dan menasehati serta memberikan contoh kerja yang benar dan baik kepada mahasiswa.

\section{UCAPAN TERIMA KASIH}

Pada kesempatan ini kami mengucapkan terima kasih kepada Bapak Wardan Suyanto, Ed.D selaku Dekan FT UNY, Bapak Bambang Setyo HP, M.Pd selaku Ketua Jurusan Mesin FT UNY yang telah membantu fasilitas penelitian; dan Kepada Bapak Prof. Pardjono, Ph.D. serta Bapak Dr. Sunaryo Sunarto atas waktunya sebagi redaktur ataupun penyunting jurnal ini.

\section{DAFTAR PUSTAKA}

Al-Emadi, M., A., S., Michael J. Marquardt, M.J. 2007. "Relationship between Employees' Beliefs Regarding Training Benefits and Employees' Organizational Commitment in a Petroleum Copany in the State of Qatar. International Journal of Training and Development. 11 (1), 49-70. 
DeGarmo, P.E. 2003. Materials and Processes in Manufacturing. New York: John Willey \& Sons, Inc.

Heywood, John. 2005. Engineering Education: Research and Development in Curriculum and Instruction. New Jersey: John Wiley \& Sons, Inc.

Kira, M. 2007. "Learning in the Process of Industrial Work - a Comparative Study of Finland, Sweden and Germany". International Journal of Training and Development. 11 (2), 86-102.

Marcus, B., Lee, K. And Asthon, M., C. 2007. "Personality Dimensions Explaining Relationships Between Integrity Tests and Counterproductive Behavior: Big Five, or One in Addition?". Personnel Psychology Journal. Vol. 60 Issue 1 pages 1-34.

Noe, R., A. et all. 2004. Human Resource Management. Boston: McGrawhill Irwin.

Olsen, J., H., Jr. 1998. “The Evaluation and Enhancement of Training Transfer". International Journal of Training and Development. 2 (1). 75.

Pio, E. 2007. “International Briefing 17: Training and Development in New Zealand". International Journal of Training and Development. 11 (1), 71-83.
Prosser, C.A. \& Allen, C.R. 1925. Vocational Education in a Democracy. New York: Century Publishing.

Rowold, J. 2007. “Individual Influences on Knowledge Acquisition in a Call Center Training Context in Germany". International Journal of Training and Development. 11 (1), 21-34.

Saran J. 1982. Aspect of Curriculum for Technician Education. Singapore: Colombo Plan College for Technician education.

Wankat, Philip C dan Oreovicz, Frank S. 1993. Teaching Engineering. Toronto: Mc Grow-Hill, Inc.

Ya Hui Lien, B., Richard Yu Yuan Hung, Gary N. McLean. 2007. "Training Evaluasi Based on Cases of Taiwanese Benchmarked High-Tech Companies". International Journal of Training and Development. 11 (1), 35-48. 